\title{
The Effect of Onosma bracteatum in cancer cells
}

\begin{abstract}
Background: One significant cause of mortality and morbidity among populations around the globe is cancer. Many plants have shown their ability for use in developing anti-cancer drugs. Approximately $60 \%$ of all anti-cancer drugs, recently in use, are a compound derived from plants. ${ }^{1}$ Several studies have shown that extracted plants are capable of inducing apoptosis, reducing the lipid peroxides in various cancer cells. Herein, we examined the underlying mechanism of Onosma bracteatum cytotoxicity in prostate cancer (PC3), lung cancer (A549), and breast cancer (BT549).
\end{abstract}

Methods: In this study, O. bracteatum leaves in methanol extract was prepared and exposed to a human breast, prostate, and lung cancer cells. Lipid peroxidation and Elisa assays were used to assess the cytotoxic effect of the O. bracteatum on BT549, PC3, and A549 cancer cells

Result: We found that $O$. bracteatum with multiple concentrations $(0.055,0.11,0.22$, $0.44,0.88,1.7$ and $3.52 \mu \mathrm{g} / \mathrm{ml})$ reduced cell viability in a dose- and time-dependent method.

The results from lipid peroxides assay indicate that the lipid peroxides (MDA) were decreased in prostate, breast, and lung cancer cells in concentration $1.76 \mu \mathrm{g} /$ $\mathrm{ml}$, compared with the control group. Furthermore, Elisa assay also revealed that caspase- 3 activated in prostate, breast, and lung cancer cells in concentration $1.76 \mu \mathrm{g} /$ $\mathrm{ml}$ compared to the control (DMSO).

Conclusion: $O$. bracteatum has potential as a drug candidate for the treatment of prostate cancer, lung cancer, and breast cancer.

Keywords: Onosma bracteatum, cancer cells, anticancer properties, drugs, lipid peroxidation

\section{Background}

Cancer is an important cause of mortality and morbidity among populations around the globe. The hallmark of cancer is perpetual growth and differentiation of cells without regulation, resulting in the transformation of cells. ${ }^{2}$ Naturally occurring plant products with potent growth inhibition and apoptosis induction properties have been widely investigated with the aim of developing anti-cancer drugs. Badmus et al. ${ }^{1}$ reported that $60 \%$ of all anti-cancer drugs, currently in use, are plant-derived compounds. A number of these products are widely recognized to possess the potential for inhibiting malignant transformation of cells as well as inducing apoptosis. The natural plant products indicate the presence of potential anti-cancerous bioactive compounds that can be extracted and isolated for further evaluation. The researcher found that there is more than three thousand extracting plant possess critical anticancer properties.

The aims of this study were first. Determine the anti-proliferative activity of $O$. bracteatum on A549 lung cancer cell line, (Figure 1) BT549 Breast cancer cell line, (Figure 2) and PC3 prostate cancer cell line, (Figure 3) Second, investigate the effect of $O$. bracteatum on Lipid Peroxidase Level in lung cancer (A549), breast cancer (BT549), and prostate cancer (PC3) Cancer cells and evaluate the activation of Caspase- 3 by $O$. bracteatum.

\section{Material and methods}

\section{Crude extraction}

The crude extractions of the organic compounds in O. bracteatum were prepared using a Soxhlet, lyophilizer, and an evaporator. The dried leaves of $O$. bracteatum were obtained from the place where
Volume 5 Issue 6 - 2018

\author{
Jawaher Albaqami,' Lewis Myles E,' \\ Venkataswarup Tiriveedhi,' William Boadi, ${ }^{2}$ \\ Nicole Driggins $\mathrm{S}^{3}$ \\ 'Department of Biological Sciences, Tennessee State University, \\ USA \\ ${ }^{2}$ Department of Chemistry, Tennessee State University, USA \\ ${ }^{3}$ Division of Math and Natural Sciences, Allen University, USA
}

Correspondence: Lewis Myles E, Department of Biological Sciences, Tennessee State University, 3500 John A Merritt Blvd, Harned Hall Room 213, Nashville, Tennessee 37209, Tel (615) 963-5789, USA, Email emylas@tnstate.edu

Received: October 22, 2018 | Published: December 05, 2018 we got the plant. These samples were placed in a separate, plastic, chemical resistant $15 \mathrm{ml}$ centrifuge tube and frozen for twenty-four hours in liquid nitrogen. The samples were then removed and ground separately with a mortar and pistil. The crude extract was then infused in methanol to remove the components distilled for 6hours in a Soxhlet. The methanol was removed with a rotary evaporator. All crude extracts were weighed and dissolved in dimethyl sulfoxide. The extracts were frozen in freeze vials and stored at -20degrees C.

\section{Analysis of Cancer Cell line A549 After 24 hour}

Expouse to Onosma bracteatum

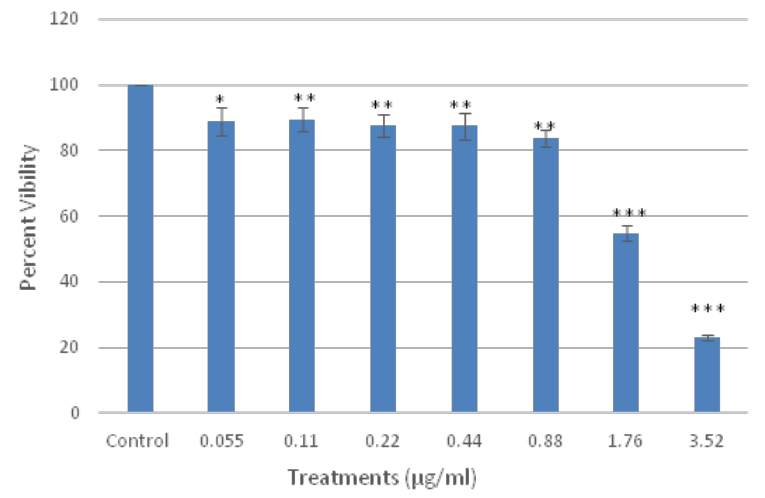

Figure 1 Effect of $O$. bracteatum on lung cancer (A549) cell lines. As shown above, the extraction of $O$. bracteatum caused an essential cell viability decrease in A549 lung cancer cells. Dose-response experiments were performed in triplicates with cells treated with $O$. bracteatum and control (DMSO) in a 96-well plate. Three separate experiments carried out displayed similar results. Control: dimethyl sulfoxide (vehicle) and several concentrations of $O$. bracteatum $(0.055,0.11,0.22,0.44,0,88,1.7$, and $3.52 \mu \mathrm{g} / \mathrm{ml})$. 


\section{Analysis of Cancer Cell line BT549 After 24 hour Exposure to Onosma bracteatum}

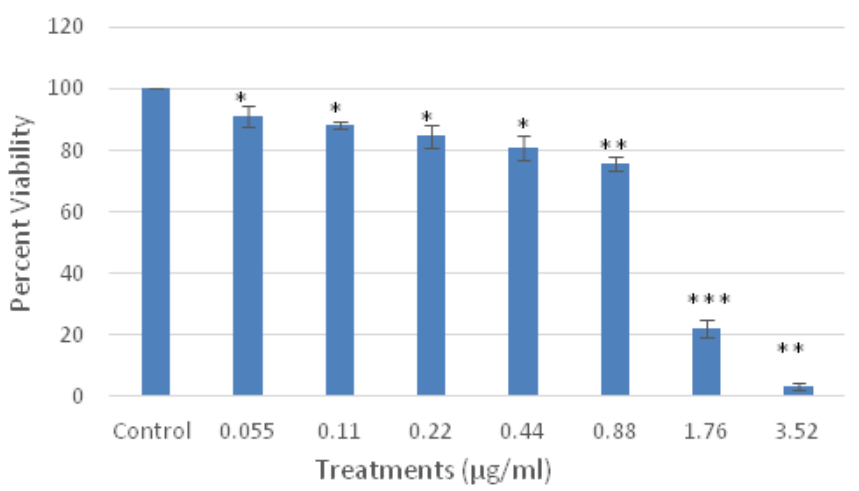

Figure 2 Effect of $O$. bracteatum on breast cancer (BT549) cell lines. As shown above, the extraction of $O$. bracteatum caused an essential cell viability decrease in BT549 breast cancer cells. Dose-response experiments were performed in triplicates with cells treated with $O$. bracteatum and control (DMSO) in a 96-well plate. Three separate experiments carried out displayed similar results. Control: dimethyl sulfoxide (vehicle) and several concentrations of $O$. bracteatum $(0.055,0.11,0.22,0.44,0,88,1.7$, and $3.52 \mu \mathrm{g} / \mathrm{ml})$.

\section{Analysis of Cancer Cell Line PC3 After 24 Hour Expouse to Onosma bracteatum}

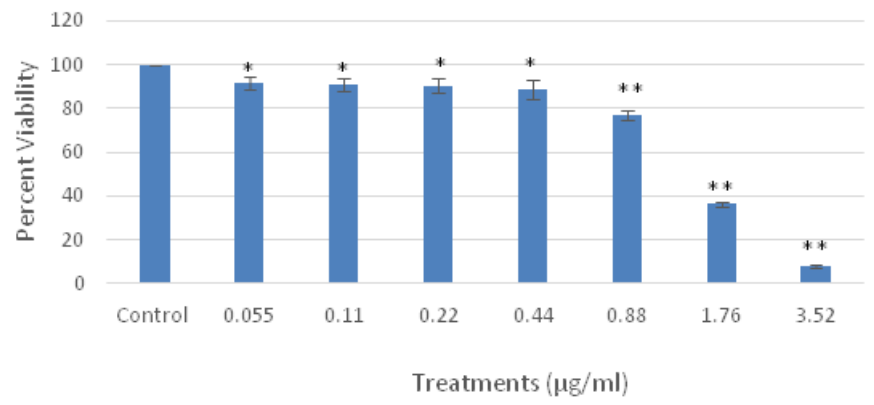

Figure 3 Effect of $O$. bracteatum on prostate cancer (PC3) cell lines. As shown above, the extraction of $O$. bracteatum caused essentially to cell viability decrease in PC3 prostate cancer cells. Dose-response experiments were performed in triplicates with cells treated with $O$. bracteatum and control (DMSO) in a 96-well plate. Three separate experiments carried out displayed similar results. Control: dimethyl sulfoxide (vehicle) and several concentrations of $\mathrm{O}$. bracteatum $(0.055,0.11,0.22,0.44,0,88,1.7$, and $3.52 \mu \mathrm{g} /$ $\mathrm{ml})$.

\section{Cell culture}

Cell lines representing common kinds of cancer were selected (A549, PC3, and BT549) and were provided by American Type Culture Collection (Rockville, MD). A549 and BT549 were maintained in RPMI-1640, and PC3 in F-12k supplemented with $10 \%$ heat-inactivated FBS, $2 \mathrm{mM}$ L-glutamine, and $1 \%$ penicillinstreptomycin, with the exception. Cells were grown in a $5 \% \mathrm{CO}_{2}$ humidified incubator at $37^{\circ} \mathrm{C}$ and passaged biweekly after reaching $80 \%$ confluency in 1:2/1:4 ratios for no more than 40 passages.

\section{Determining growth analysis at various concentrations}

\section{Making stock serial dilutions}

Begin by labeling seven different $2.0 \mathrm{ml}$ tubes 0 through 6 for each compound. Then add $1 \mathrm{ml}$ of extract to tube 0 . Then add $0.5 \mathrm{ml}$ of DMSO to tubes 1 through 6. Now make a 1:2 serial dilution from 0 (pure extract) to 6(1:16) (Figure 4).

\section{Lipid Peroxides in PC3 Cancer Cells After 24 h Exposure to Onosma bracteatum}

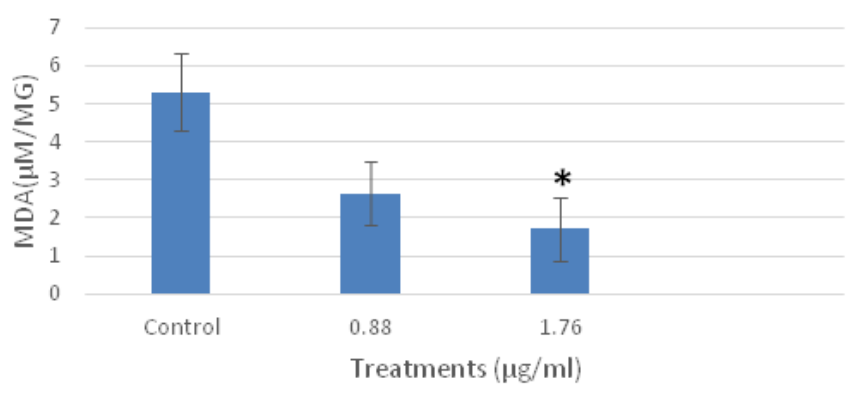

Figure 4 The effects of $O$. bracteatum extract on the level of lipid peroxides (MDA) in PC3 cells. The cells were treated with different concentrations of the extract $(0.88 \mu \mathrm{g} / \mathrm{ml}$ and $1.76 \mu \mathrm{g} / \mathrm{ml})$ for $24 \mathrm{~h}$, then measured the level of MDA. The level of MDA decreased in the concentration of $1.76 \mu \mathrm{g} / \mathrm{ml}$ compared to the control.The result is the means \pm SEM from three independent experiments. It is significantly different from the unexposed control (DMSO) $* p<0.05$.

\section{Experimental procedure}

Begin by labeling two sets of 7 different $1.5 \mathrm{ml}$ tubes 0 through 6. Obtain one more $1.5 \mathrm{ml}$ tube and label it B for the blank. Obtain 1 sample of $15 \mu \mathrm{ls}$ from each of the serially diluted tube concentrations and put it in its corresponding $1.5 \mathrm{ml}$ tube. Add $525 \mu \mathrm{l}$ of media to each $1.5 \mathrm{ml}$ tube, followed by $60 \mu \mathrm{l}$ of Alamar Blue in each tube. To make the blank, add $180 \mu \mathrm{l}$ of media and $20 \mu 1$ of Alamar Blue in another $1.5 \mathrm{ml}$ tube. Next, obtain a 96 well plate and take 1 sample of $190 \mu 1$ from the blank and put it in well \#A1. Then take three different $190 \mu \mathrm{l}$ samples of concentration 0 and put it in Wells F2, G2, and H2. Repeat this step by taking three more different $190 \mu 1$ samples of concentration 1 and putting it in wells F3, G3, H3. Continue this same procedure consecutively for the remaining concentrations. Again, label $71.5 \mathrm{ml}$ tubes 0 thru 6 . Place $15 \mu$ of each serially diluted extract into its corresponding labeled tube.

Next, add $465 \mu 1$ of media into each tube. Then $60 \mu 1$ of Alamar blue in each tube. Finally, add $60 \mu 1$ of cells (adjusted to 10,000 cells $/ 20 \mu 1$ ). Now, take three different samples $190 \mu 1$ samples of concentration 0 and put them in wells A2, B2, and C2. Repeat this step by taking 3 more different $190 \mu 1$ samples of concentration 1 and putting them in wells A3, B3, and C3. Continue this same procedure consecutively for the remaining concentrations. Finally, place the 96 well plates in a $\mathrm{CO} 2$ incubator $\left(37^{\circ} \mathrm{C}\right)$ for 24 hours and read on a fluorescent spectrophotometer.

\section{Lipid peroxidation assay}

The cell was plated in six-well plates until they reached $70-100 \%$ confluency, and $O$. bracteatum compound $(1.76$ and $0.88 \mu \mathrm{g} / \mathrm{ml})$ and DMSO (Vehicle Control) were incubated for 24hours. The plate was rinsed with $1 \mathrm{ml}$ of $1 \mathrm{x}$ PBS. We added $600 \mu 1$ of trypsin and $600 \mu 1$ of media and centrifuged them, put $110 \mu 1$ of $1 \mathrm{x}$ PBS in the pellets and sonicated them using sonicator tool, and added $50 \mu 1$ of the sample in MDA assay 1.5 tubes and 50 $\mu 1$ in Bradford assay 1.5 tubes (Figure 5).

\section{MDA assay}

We added R1(kit purchased MD Biosciencesinc) $163 \mu 1$ in each 
tube of the samples, $\mathrm{HCl} 37.5 \mu \mathrm{l}$ in one sample tube, added the sample tube in water path $50^{\circ} \mathrm{C}$ for 1 hour, and added $200 \mu$ l of the samples in 96 well plate and measured in the Microplate Reader(Filter Max). The absorbance was read in wavelength $586 \mathrm{~nm}$.

\section{Lipid Peroxides in BT549 Cancer Cells After $24 \mathrm{H}$ Expousre to Onosma bracteatum}

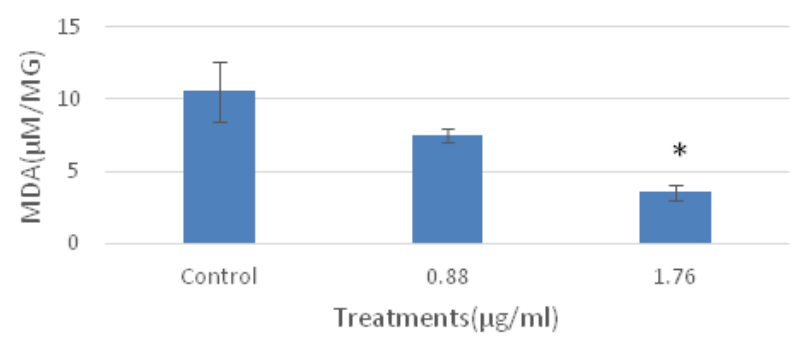

Figure 5 The effects of $O$. bracteatum extract on the level of lipid peroxides (MDA) in BT549 cells. The cells were treated with different concentrations of the extract $(0.88 \mu \mathrm{g} / \mathrm{ml}$ and $1.76 \mu \mathrm{g} / \mathrm{ml})$ for $24 \mathrm{~h}$, and then measured the level of MDA. The level of MDA decreased in the concentration of $1.76 \mu \mathrm{g} / \mathrm{ml}$ compared to the control. The result is the means \pm SEM from three independent experiments. It is significantly different from the unexposed control (DMSO) $* p<0.03$.

\section{Bradford assay}

We added $250 \mu 1$ of Coomassie Plus (Bradford) Assay Reagent to the sample tube, incubated for a half hour in $37^{\circ} \mathrm{C}$, added $220 \mu 1$ in 96 well plates, and measured in the microplate reader (FilterMax). Lastly, the absorbance was read in wavelength $620 \mathrm{~nm}$.

\section{Caspase-3 activity assay (Elisa)}

The cell was plated in six-well plates until they reached $70-100 \%$ confluency, $O$. bracteatum compound $(1.76,0.88$, and $0.44 \mu \mathrm{g} / \mathrm{ml})$ and DMSO (Vehicle Control) were added, and it was incubated for 48hours (Figure 6). The plate was rinsed with $1 \mathrm{ml}$ of $1 \mathrm{x}$ PBS, $600 \mu \mathrm{l}$ of trypsin was added, media was added, and they were centrifuged and lysed $60 \mu 1$ with Cell lytic M Cell lysis reagent (Sigma-Aldrich, St Louis, MO, USA). We added $20 \mu 1$ triplication of laying cells in 96 well plate, added $180 \mu 1$ of $5 \%$ BSA ( Blocking agent ), incubated the plate overnight in $4^{\circ} \mathrm{C}$, washed the plate with $300 \mu 1$ of $1 \mathrm{x}$ washing buffer, added $100 \mu 1$ of dilution caspase- 3 rabbit primary antibody (cell signal company), and incubated the plate for 24 hours in $4^{\circ} \mathrm{C}$. We washed the plate with $300 \mu \mathrm{l}$ of $1 \mathrm{x}$ washing buffer. We then added $100 \mu \mathrm{l}$ of dilution anti-rabbit HRP- linked antibody (Secondary antibody, cell signal company) in the samples, incubated them for 1 hour in $37^{\circ} \mathrm{C}$, washed the plate twice with $300 \mu 1$ of the $1 \mathrm{x}$ washing buffer. We mixed and added substrate Reagent A and B and added with $100 \mu$ in the samples and incubated half hour in $37^{\circ} \mathrm{C}$, stop solution was added with $50 \mu 1$, and the samples measured in the absorbance was read in a microplate reader (Filter Max) at wavelength $450 \mathrm{~nm}$.

\section{Result}

\section{Effect of O. bracteatum on cell viability on the growth of PC3 (prostate), A549 (lung), and BT549 (breast) cancer cell lines}

We determined the cytotoxicity of $O$. bracteatum on cancer cells, three cell lines- PC3 (Prostate), A549 (lung), and MCF-7 (breast) were tested, and cell viability was assessed using cell viability assay. Cancer cells were incubated with several concentrations of $O$. bracteatum $(0.055,0.11,0.22,0.44,0.88,1.7$, and $3.52 \mu \mathrm{g} / \mathrm{ml})$ to study its effects on cell viability using dose-response experiments. Doseresponse experiments showed that $O$. bracteatum was sensitive to A549 lung cancer cells, BT549 breast cancer cells, and PC3 prostate cancer cells. O. bracteatum induced approximately $96 \%$ of cell death in a $\mathrm{PC} 3$ cancer cell in the highest concentration of $O$. bracteatum (Figure 3). There were 98, 79, 22\% remarkable decreases in the three highest concentrations $(3.52,1.76$, and $0.88 \mu \mathrm{g} / \mathrm{ml})$ of $O$. bracteatum in BT549 cancer cells respectively, as compared to the cell viability of vehicle (DMSO) treated control cells (Figure 7). Subsequently, A549 cells showed that there were 78, 42, $18 \%$ reduced cell viability (Figure 1).

\section{The effect of $\mathrm{O}$. bracteatum on lipid peroxidase on $\mathrm{PC} 3$ (prostate),A549 (lung), and BT549 (breast) cancer cell lines}

Malondialdehyde (MDA) is the popular marker of lipid peroxidation and used to detect the oxidative change. MDA is the end product of lipid peroxidation and is reportedly being higher in the cancer cell. We evaluated whether $O$. bracteatum would affect the cell's ability to assemble lipid peroxidase as measured by the production of malondialdehyde (MDA) within the cells, and cells were treated with $O$. bracteatum $(0.88 \mu \mathrm{g} / \mathrm{ml}$ and $1.76 \mu \mathrm{g} / \mathrm{ml})$ for 24hours. The cell was lysate for the measurement of MDA production as described in the Materials and Methods section. As shown in Figure 5-7, treatments of this PC3, A549, and BT549 cells with different concentrations of $O$. bracteatum for $24 \mathrm{~h}$ caused a significant decrease in MDA levels in concentration $1.76 \mu \mathrm{g} / \mathrm{ml}$, compared with the control group. However, in concentration $0.88 \mu \mathrm{g} / \mathrm{ml}$ had no significant effect on the levels of MDA, compared with the cells treated with control (DMSO) (Figure 8).

\section{Lipid Peroxides in A549 Cancer Cells After $24 \mathrm{H}$ Exposure to Onosma bracteatum}

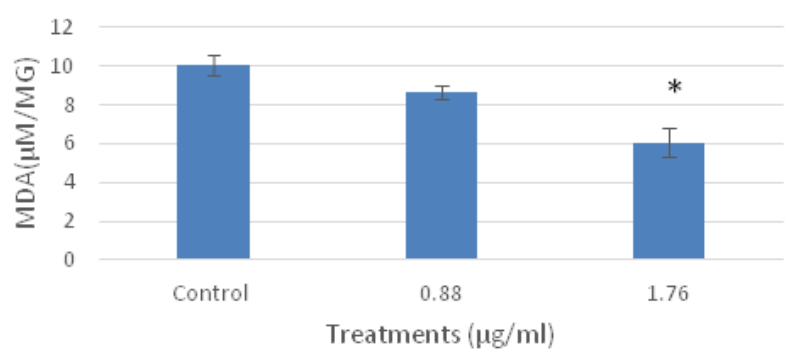

Figure 6 The effects of O. bracteatum extract on the level of lipid peroxides (MDA) in A549 cells. The cells were treated with different concentrations of the extract $(0.88 \mu \mathrm{g} / \mathrm{ml}$ and $1.76 \mu \mathrm{g} / \mathrm{ml})$ for $24 \mathrm{~h}$, and then measured the level of MDA. The level of MDA decreased in the concentration of $1.76 \mu \mathrm{g} / \mathrm{ml}$ compared to the control. The result is the means \pm SEM from three independent experiments. It is significantly different from the unexposed control (DMSO) $* \mathrm{p}<0.01$

\section{Evaluate the activation of Caspase-3 on PC3 (prostate), A549 (lung), and BT549 (breast) cancer cell lines by $O$ bracteatum}

We investigated whether caspase- 3 activated during $O$. bracteatum exposure, and it was evaluated by Elisa assay using anti-caspase-3. 
PC3, A549, and BT549 cells were exposed to O. bracteatum, and the result was that the treatment of the cells with $O$. bracteatum showed a significant increase in caspase- 3 activity compared with DMSO treatment (control) (Figure 9). However, no significant increase in caspase-3 activity was observed in concentration $(0.88 \mu \mathrm{g} / \mathrm{ml})$. A 48-hour exposure to $1.76 \mu \mathrm{g} / \mathrm{ml} \mathrm{O}$. bracteatum increased the activity of caspase-3 in the three types (PC3, A549, and BT549) of cancer cells. These results suggest that the growth inhibitory effect of $O$. bracteatum in the A549, BT549, and PC3 cells was due to apoptotic cell death.

\section{Caspase-3 Activity on A549 Cancer Cell line After $48 \mathrm{H}$ Exposure to Onosma bracteatum}

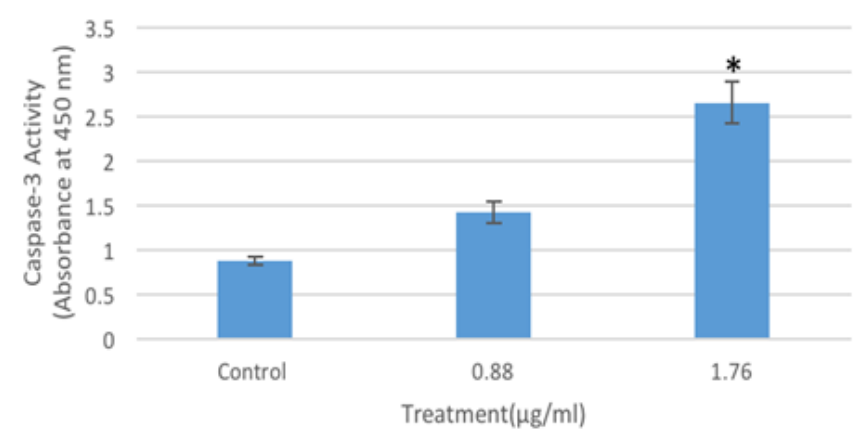

Figure 7 Determination caspase-3 activation by Elisa assay designed to detect the activation of caspase-3. A549 cells were treated with different concentration of $\mathrm{O}$. bracteatum $(1.76$, and $0.88 \mu \mathrm{g} / \mathrm{ml})$ for 48 hours and measured the caspase- 3 activation. The data represent the mean $\pm \mathrm{SEM}$ of three separate experiments. As shown above, in concentration 1.76 has significant difference compared with the control (DMSO) $(\mathrm{p}<0.001)$.

\section{Caspase-3 Activity on PC3 Prostate Cancer Cell line After $48 \mathrm{H}$ Expouser to Onosma bracteatum}

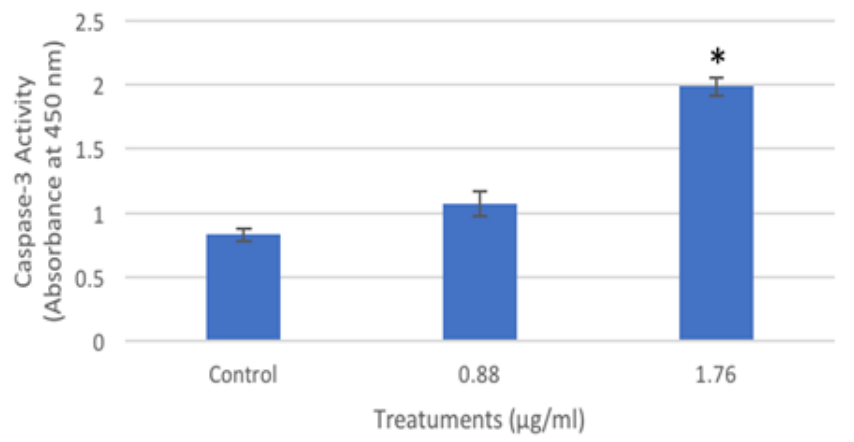

Figure 8 Determination caspase- 3 activation by Elisa assay designed to detect the activation of caspase- 3 . PC3 cells were treated with different concentration of O. bracteatum $(1.76$, and $0.88 \mu \mathrm{g} / \mathrm{ml})$ for 48 hours and measured the caspase- 3 activation. The data represent the mean $\pm \mathrm{SEM}$ of three separate experiments. As shown above, in concentration 1.76 has significant difference compared with the control (DMSO) $(\mathrm{p}<0.0001)$.

\section{Discussion}

Cancer may be a vital reason for mortality and morbidity among populations around the globe. Natural products such as plants, fungi, bacteria, and other organisms in place of modern therapies are used, and much of the attention has been used against this issue. However, Aung et al. ${ }^{3}$ demonstrated that consolidated utilization of specific phytochemicals with the medications could support the cytotoxicity to cancer cells while downregulating obstruction. The natural plant has been widely examined with a target of developing anti-cancer drugs. Badmus et al. ${ }^{1}$ reported that $60 \%$ of all anti-cancer agents, currently in use, are the plant-derived various types of compounds. However, there is a study on the effect of $O$. bracteatum in the anti-allergic and anti-inflammatory investigated by Kalpana et al. ${ }^{4}$ using dried extracts since it is traditionally prescribed as an anti-asthmatic agent in the Indian medical system of Ayurveda.

\section{Caspase-3 Activity on BT549 Cancer Cell line After $48 \mathrm{H}$ Expouser to Onosma bracteatum}

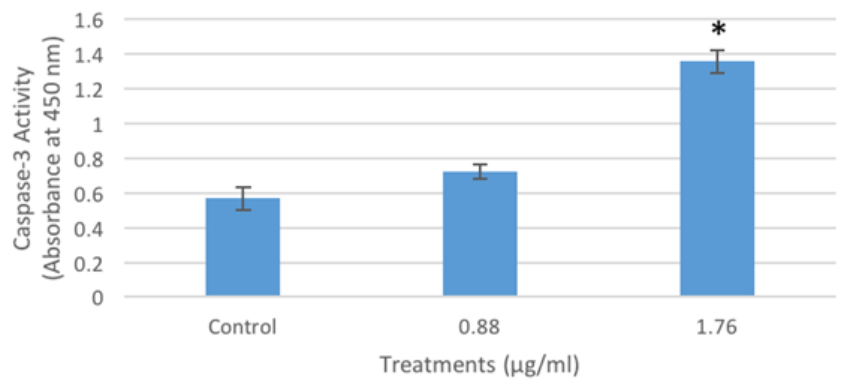

Figure 9 Determination caspase- 3 activation by Elisa assay designed to detect the activation of caspase-3. BT549 cells were treated with different concentration of $\mathrm{O}$. bracteatum $(1.76$, and $0.88 \mu \mathrm{g} / \mathrm{ml})$ for 48 hours and measured the caspase- 3 activation. The data represent the mean $\pm \mathrm{SEM}$ of three separate experiments. As shown above, in concentration 1.76 has significant difference compared with the control (DMSO) $(\mathrm{p}<0.001)$.

Furthermore, clear investigations were illustrating the connection between inflammation and cancer by Lisa and Zena, ${ }^{5}$ that cancer development can be affected by inflammatory cells. ${ }^{6}$ Inflammatory cells can produce an attractive environment for cancers growth, facilitating genomic instability and promoting angiogenesis. The pro-cancer actions of inflammatory cells include release growth and survival factors, promoting angiogenesis and lymphangiogenesis, stimulating DNA damage. So, $O$. bracteatum has been investigated by studies for its effect in inflammatory, and we investigated its implication in cancer cells. ${ }^{7}$ The finding from this study observed the anti-proliferative activity of $O$. bracteatum on A549 lung cancer cell line, BT549 breast cancer cell line, and PC3 prostate cancer cell line. ${ }^{8}$ Also, there was an effect of $O$. bracteatum on Lipid Peroxidase Level in lung cancer (A549), breast cancer (BT549), and prostate cancer (PC3) cells, and the activation of Caspase- 3 by $O$. bracteatum was evaluated. We have conducted series of assays like cell viability/ proliferation, effect on cell ROS generation, and cell apoptosis or assessing the effect of $O$. bracteatum against the selected A549 lung cancer, BT549 breast cancer, and PC3 prostate cancer cells. ${ }^{9}$ Several plants have been shown to have a chemo-preventive influence on lung cancer (A549), breast cancer (BT549), and prostate cancer (PC3). We provide clear evidence that $O$. bracteatum exerts multiple different suppressive effects on PC3, A549, and BT549 cancer cells in vitro. ${ }^{10,11}$

\section{Conclusion}

In conclusion, our results are the first to describe a potent antiproliferative effect of $O$. bracteatum on the growth on cancer cell lines studied particularly on prostate, lung, and breast cell lines in vitro. The results focus on the importance of the $O$. bracteatum as an attractive agent against breast, lung, and prostate cancer in general. One of the 
critical aspects of our investigation is that the $O$. bracteatum is more varied towards inhibition of A459, BT54, and PC3. Results of our investigation have established the significance of Onosma bracteaum as an effective resource of metabolites, which could be more explored for the development of novel anti-cancer agents targeting prostate cancer, breast cancer, and lung cancer. The results may also act as a ready reference towards developing $O$. bracteatum based formulation as an alternative and complementary medicine for the management of lung cancer, prostate cancer, and breast cancer. ${ }^{12}$

\section{Acknowledgments}

None.

\section{Conflicts of interest}

Author declares that there are no conflicts of interest.

\section{References}

1. Badmus JA, Ekpo OE, Hussein AA, et al. Antiproliferative and Apoptosis Induction Potential of the Methanolic Leaf Extract of Holarrhena floribunda (G. Don). Evid Based Complement Alternat Med. 2015;2015:756482.

2. Fouad YA, Aanei C. Revisiting the Hallmarks of Cancer. Am J Cancer Res. 2017;7(5):1016-1036.

3. Aung TN, Qu Z, Kortschak RD, et al. Understanding the Effectiveness of Natural Compound Mixtures in Cancer through Their Molecular Mode of Action. Int J Mol Sci. 2017;18(3):656.

4. Kalpana G Patel. Evaluation of The Effect of O. bracteatum Wall (Boraginaceae) on Bronchial Hyperreactivity in Sensitized Guinea Pigs. 2008;7(1):35.
5. Coussens LM, Werb Z. Inflammation and Cancer. Nature. 2002;420(6917):860-867.

6. Amara S, Lopez K, Banan B, et al. Synergistic effect of pro-inflammatory TNFa and IL-17 in periostin mediated collagen deposition: Potential role in liver fibrosis. Mol Immunol. 2015;64(1):26-35.

7. Platt D, Amara S, Mehta $T$, et al. Violacein inhibits matrix metalloproteinase mediated CXCR4 expression: Potential antitumor effect in cancer invasion and metastasis. Biochem Biophys Res Commun. 2014;455(1-2):107-112.

8. Mehta T, Vercruysse K, Johnson T, et al. Violacein induces $\mathrm{p} 44 / 42$ mitogen-activated protein kinase-mediated solid tumor cell death and inhibits tumor cell migration. Mol Med Rep. 2015;12(1):1443-1448.

9. Agbaje OC, Fadeyi OO, Fadeyi SA, et al. Synthesis and in Vitro Cytotoxicity evaluation of some fluorinated hexahydropyrimidine derivative. Bioorg Med Chem Lett. 2011;21(3):989-992.

10. Paul A, Das S, Das J, et al. Diarylheptanoid-myricanone isolated from ethanolic extract of Myrica cerifera shows anticancer effects on HeLa and PC3 cell lines: signalling pathway and drug-DNA interaction. $J$ Integr Med. 2013;11(6):405-415.

11. Fadeyi SA1, Fadeyi OO, Adejumo AA, et al. In vitro anticancer screening of 24 locally used Nigerian medicinal plants. BMC Complement Altern Med. 2013;13:79.

12. Steffani N Driggins, Margaret Whalen, Elbert Lewis Myles. The Inhibitory Effect of Echinacea purpurea and Echinacea pallida on BT549 and Natural Killer Cells. MOJ Cell Sci Rep. 2017;4(3):88-96. 